\title{
Percutaneous retrieval of a broken umbilical vein catheter from left atrium in a premature newborn case report and literature review
}

\author{
Mohammed Habib ${ }^{1 *}$ and Mohammed Hillis ${ }^{2}$ \\ ${ }^{1}$ Cardiology Department, Alshifa Hospital, Gaza, Palestine \\ ${ }^{2}$ Pediatric Cardiology Department, Alshifa Hospital, Gaza, Palestine
}

\begin{abstract} approach.

\section{Introduction}

Umbilical catheters are often used in preterm infants as central venous access for fluid, drug administration, and blood sampling in intensive care units. When used properly, they are generally safe but there are various complications associated with the UVC, such as infection, arrhythmia, embolization, and catheter fracture [1-3]. Catheter fracture is an uncommon but very challenging complication for clinicians. Fractured Catheter segments can be retrieved by surgical or percutaneous techniques.
\end{abstract}

A 28-week-old preterm infant with a birth weight of $1370 \mathrm{~g}$ had a broken segment of umbilical vein catheter (UVC) lodged in the left atrium. It was observed that a 10 -cm fragment of catheter had migrated to the left atrium appendage through the patent foramen ovale. The catheter was successfully retrieved by fluoroscopically guided percutaneous cardiac catheterization using grasping forceps after failed many trials of snare wire without complication.

Presently described was a case of fractured and embolized UVC in a very low-birth weight preterm infant, and its successful retrieval via percutaneous endovascular

\section{Case report}

A 28-week-old preterm infant with a birth weight of $1370 \mathrm{~g}$ was born by cesarean section. He was admitted to neonatal intensive care unit because of respiratory distress due to meconium aspiration syndrome. He was intubated, mechanically ventilated, A 3.5 Fr UVC was used during initial days of his stay for parenteral nutritional support. After hemodynamic and respiratory stabilization, the UVC was removed on the fourth day of life, but during catheter removal the UVC got divided by a scalpel at the skin level while removing the retaining suture. An attempt to retrieve the fractured portion of UVC was planned by a local exploration but the end had retracted into the lumen of the umbilical vein and it was not visible. During manipulation, the catheter got accidentally transected and embolized into the left atrium with its one end still remaining in the inferior vena cava (IVC) (Figure 1).

Patient was transferred urgently to cardiac catheterization for removal fractured segment by percutaneous technique.

Informed consent was obtained from the patient's parents. Under general anesthesia trans-umbilical vein access was done. Intravenous heparin $(100 \mathrm{IU} / \mathrm{kg})$ was administered. Cut down of Umbilical vein was done, then 0.018-in floppy guidewire was cross and advanced into umblicial vein (Figure 2), and floppy guidewire was exchanged with a five French venous sheath. The fractured fragment of UVC was retrieved with fluoroscopically guided, Though we could hold the catheter very well with the snare, its snared end was making a loop and could not be retrieved back into the $5 \mathrm{~F}$ sheath, then small size grasping forceps was cross and catch the distal edge of fractured segment and removal without complications.

Total procedural time was 35 minutes, with 4 minutes of fluoroscopy. Control fluoroscopy demonstrated total removal of the broken UVC (Figure 3). Blood loss during the procedure was minimal.

\section{Discussion}

The UVC have contributed a great deal in managing critically ill

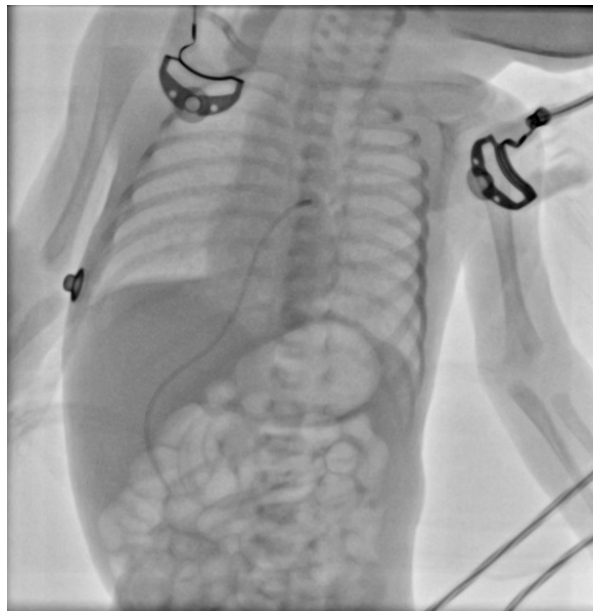

Figure 1. Broken UVC migration via patent foramen oval to left atrial appendage.

Correspondence to: Mohammed Habib, Cardiology Department, Alshifa Hospital, Gaza, Palestine, E-mail: cardiomohammad@yahoo.com

Received: December 03, 2016; Accepted: December 21, 2016; Published: December 24, 2016 
Habib M (2016) Percutaneous retrieval of a broken umbilical vein catheter from left atrium in a premature newborn case report and literature review

Table 1. Listed of umbilical vein catheter fracture.

\begin{tabular}{|c|c|c|c|c|c|c|c|c|}
\hline No & year & Authors & $\begin{array}{l}\text { No. of } \\
\text { cases }\end{array}$ & Gestation al Age & Gestation al Weight & $\begin{array}{l}\text { UVCin Umbilical } \\
\text { Artery (A) or Vein }\end{array}$ & Lodged at & Retrieval \\
\hline 1 & 1972 & {$[6]$} & 1 & NA & NA & $\mathrm{A}$ & Thoracic aorta & Open \\
\hline \multirow[t]{2}{*}{2} & \multirow[t]{2}{*}{1977} & \multirow[t]{2}{*}[5]{} & \multirow[t]{2}{*}{2} & 32- weeks & 1310gms & A & Umbilical artery & Open \\
\hline & & & & 28- weeks & $950 \mathrm{gms}$ & A & Thoracic Aorta & Not retireved \\
\hline \multirow[t]{2}{*}{3} & \multirow[t]{2}{*}{1978} & \multirow[t]{2}{*}{ [7] } & \multirow[t]{2}{*}{2} & 33- weeks & $1370 \mathrm{gms}$ & A & Femoral artery & Wire loop \\
\hline & & & & 32- weeks & 1370 gms & $\mathrm{V}$ & Umbilical vein & Loop snare \\
\hline 4 & 1987 & [8] & 1 & NA & NA & A & Extremity vessel & Open \\
\hline 5 & 1987 & [9] & 1 & 37-weeks & 3200 gms & $\mathrm{V}$ & $\begin{array}{l}\text { One end in left atrial } \\
\text { appendage other end } \\
\text { in ductusvenosus }\end{array}$ & Endovascular (trans-femoral) \\
\hline 6 & 1995 & [3] & 1 & 30 -week & $1117 \mathrm{gms}$ & $\mathrm{V}$ & $\begin{array}{l}\text { Left superior } \\
\text { pulmonary vein }\end{array}$ & $\begin{array}{l}\text { Percutaneous pigtail catheter and a } \\
\text { snare wire with fluoroscopy }\end{array}$ \\
\hline 7 & 1995 & {$[10]$} & 1 & NA & NA & A & Umbilical artery & Open (trans- umbilical) \\
\hline \multirow[t]{2}{*}{8} & \multirow[t]{2}{*}{1997} & \multirow[t]{2}{*}{ [11] } & \multirow[t]{2}{*}{2} & 29-weeks & $815 \mathrm{gms}$ & A & Umbilical artery & Loop snare \\
\hline & & & & 31- weeks & $1117 \mathrm{gms}$ & $\mathrm{V}$ & Umbilical vein & Pigtail+ Snare \\
\hline 9 & 1998 & [12] & 1 & 26-weeks & $870 \mathrm{gms}$ & $\mathrm{V}$ & Umbilical vein & $\begin{array}{l}\text { Open cutdown + wire loop using } \\
\text { fluoroscopy }\end{array}$ \\
\hline 10 & 2000 & {$[13]$} & 1 & NA & NA & A & Common ilica artery & Open ( infra- umbilical) \\
\hline 11 & 2004 & {$[14]$} & 1 & 38- weeks & $3761 \mathrm{gms}$ & $\mathrm{U}$ & Umbilical vein & $\begin{array}{l}\text { Open dissection+ endovascular } \\
\text { through umbilical vein }\end{array}$ \\
\hline 12 & 2007 & {$[15]$} & 1 & 27- weeks & NA & A & Umbilical artery & Laparotomy \\
\hline 13 & 2013 & {$[16]$} & 1 & 26- weeks & NA & $\mathrm{V}$ & Umbilical vein & Open (supra-umbilical) \\
\hline 14 & 2013 & {$[17]$} & 1 & 37- weeks & $1800 \mathrm{gms}$ & $\mathrm{V}$ & $\begin{array}{l}\text { Across right atrium } \\
\text { with one end in SVC } \\
\text { other end in IVC }\end{array}$ & $\begin{array}{l}\text { Open (Supra-umbilical) failed then } \\
\text { Endovasular ( Trans- femoral) }\end{array}$ \\
\hline 15 & 2014 & {$[18]$} & 1 & 38- weeks & $970 \mathrm{gms}$ & $\mathrm{V}$ & Pulmonary artery & Loop snare \\
\hline 16 & 2015 & [19] & 1 & 40 weeks & 4000 gms & $\mathrm{V}$ & Umbilical vein & Open \\
\hline 17 & 2016 & [20] & 1 & 38 weeks, & $1250 \mathrm{gms}$ & $\mathrm{V}$ & Right atrium & Wire loop \\
\hline 18 & 2017 & Our case & 1 & 38 weeks & $1400 \mathrm{gms}$ & $\mathrm{V}$ & Left atrial appendage & $\begin{array}{l}\text { Loop snare failed then grasping } \\
\text { forceps }\end{array}$ \\
\hline
\end{tabular}

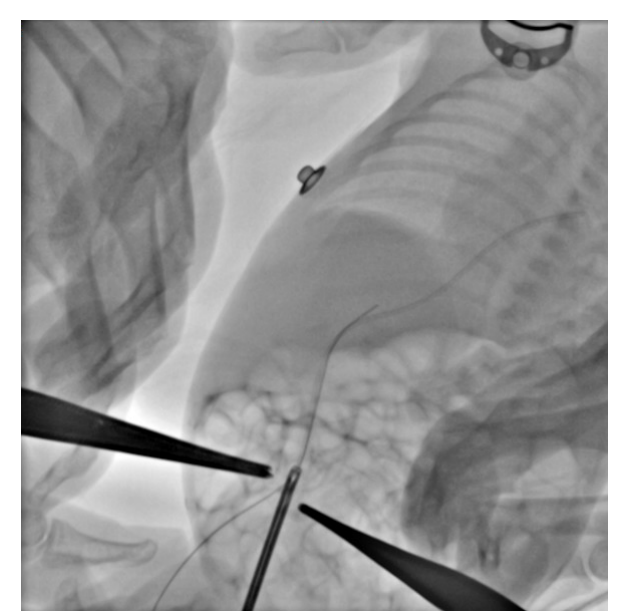

Figure 2. 0.018 -in floppy guidewire was cross and advanced into umblicial vein

patients in NICU. Complications are related to positioning and long duration of catheterization. Lodged fragments of catheter are relatively very rarely reported. These complications include nosocomial sepsis, vasospasm, vascular perforation, thrombosis, emboli (air, thrombus)

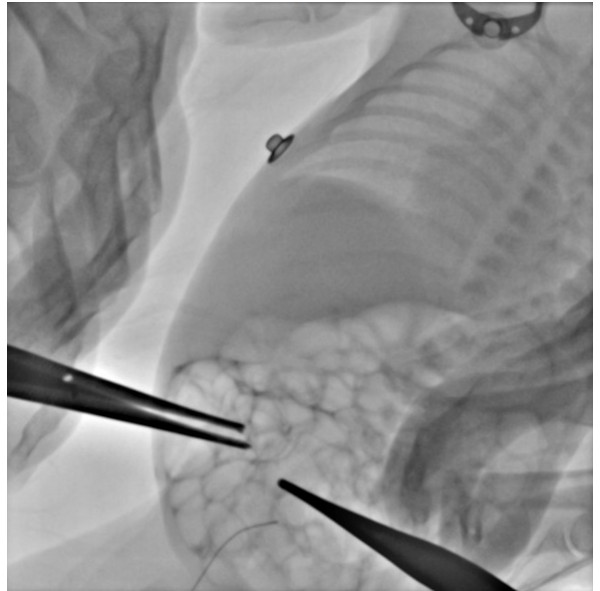

Figure 3. Control fluoroscopy demonstrated total removal of the broken UVC.

and catheter fracture [1-4].

The mechanism of UVC breakage has been proposed and discussed by Choi et al. [5]. He reported two cases of broken UVC 
and proposed that it is possible that the UVC can get inadvertently damaged by needles or scissors during catheter insertion and fixation many methods of removal have been described, including surgical techniques, percutaneous retrieval via snaring or biopsy forceps.

An exhaustive search of the literature revealed only 17 articles with 20 cases of broken UVC in neonates (Table 1).

Included our case, totally 21 cases were analyzed. Gestational Age were (26-38) weeks. Gestation weight were (970 to 4000) grams. The catheter was placed and broken in umbilical artery in 9 cases and in umbilical vein in 12 cases. Totally 12 cases the broken catheter was removed by surgical techniques, 8 cases was removal by different percutaneous intervention (snaring or biopsy forceps) and in one case the broken catheter was not retrieved.

Gasparis et al. [15] described a successful removal of a dislodged UVC through the umbilical vein using endovascular Amplatz loop snare. This minimally invasive route was also used by Ruiz et al. [3] who have reported successful retrieval of a broken umbilical vein catheter lodged in the left superior pulmonary vein from a 30 week preterm neonate.

We initially resorted to umbilical vein cut down and exploration as the lower end but this attempt failed. A check radiograph revealed that the broken fragment of UVC had actually migrated higher up and hence its removal was possible only by endovascular method and it was then successfully performed by a trans-umbilical approach by the interventional cardiologist using a goose neck snare but this attempt also failed. In the last we trial to removal a broken umbilical vein catheter by small grasping forceps via umbilical via a 5-F standard snare sheath.

\section{Conclusion}

Umbilical venous catheterization is very common in the care of preterm newborn. Complications in such common invasive interventions cannot be avoided. Fracture and embolization of a UVC is a rare but serious complication. Presently reported was the successful retrieval of a fractured and embolized UVC in a preterm infant, via percutaneous endovascular approach, without complication.

\section{References}

1. Massin M, Lombet J, Rigo J (1997) Percutaneous retrieval of broken silastic catheter from the left atrium in a critically Ill premature infant. Cathet Cardiovasc Diagn 42: 409-11. [Crossref]

2. Ochikubo CG, O’Brien LA, Kanakriyeh M, Waffarn F (1996) Silicone-rubber catheter fracture and embolization in a very low birth weight infant. $J$ Perinatol 16: 50-52. [Crossref]

3. Ruiz CE, Nystrom GA, Butt AI, Zhang HP (1995) Percutaneous retrieval of a broken umbilical catheter from left atrium in a premature newborn. Cathet Cardiovasc Diagn 36: 265-268. [Crossref]

4. Kanto WP Jr, Parrish RA Jr (1977) Perforation of the peritoneum and intra-abdomina hemorrhage: a complication of umbilical vein catheterizations. Am J Dis Child 131: 1102-1103. [Crossref]

5. Choi SJ, Raziuddin D, Haller JO (1977) Broken umbellical artery catheter: a report of two cases. Am J Dis Child 131: 595. [Crossref]

6. Lackey DA, Taber P (1972) An unusual complication of umbilical artery catheterization. Pediatrics 49: 281-283. [Crossref]

7. Smith PL (1978) Umbilical catheter retrieval in the premature infant. J Pediatr 93: 499-502. [Crossref]

8. Wagner CW, Vinocur CD, Weintraub WH (1987) Retrieval of an umbilical artery catheter: a potential for misadventure. South Med J 80: 1434-1435. [Crossref]

9. Gross DM, Cox MA, Denson SB, Ferguson L (1987) Unique use of a tip-deflecting guide wire in removing a catheter embolus from an infant. Pediatr Cardiol 8: 117-119. [Crossref]

10. Murphy KD, Le VA, Encarnacion CE, Palmaz JC (1995) Transumbilical intravascular retrieval of an umbilical artery catheter. Pediatr Radiol 25: S178-179. [Crossref]

11. Simon-Fayard EE1, Kroncke RS, Solarte D, Peverini R (1997) Nonsurgical retrieval of embolized umbilical catheters in premature infants. J Perinatol 17: 143-147. [Crossref]

12. Brion LP, Kerr A, Weinberg G, Goldman H (1998) Umbilical venous catheter retrieval under fluoroscopy in a very low-birth-weight infant. Am J Perinatol 15: 93-95. [Crossref]

13. Kotnis R, Salloum A, Hitchcock R (2000) Retained umbilical artery catheter presenting as an umbilical abscess. Arch Dis Child Fetal Neonatal Ed 83: F77. [Crossref]

14. Gasparis AP, Santana D, Blewett C, Bohannon WT, Silva MB Jr (2004) Endoluminal retrieval of a dislodged umbilical vein catheter--a case report. Vasc Endovascular Surg 38: 583-586. [Crossref]

15. Mitchell RT, Thompson R, Thomas S (2007) Surgical retrieval of a transected umbilical artery catheter. Neonatal Netw 26: 133-134. [Crossref]

16. Smith JP, Cusick EL, Johnson N, Mackenzie S, Harding D (2013) Surgical retrieval of transected umbilical catheter from preterm infant. Arch Dis Child Fetal Neonatal Ed 98: F181. [Crossref]

17. Dhua AK, Singh B, Kumar D, Awasthy N (2013) Broken Umbilical Vein Catheter as an Embolus in a Neonate-An Unusual Preventable Complication. J Neonatal Surg 2: 45. [Crossref]

18. Nigam A, Trehan V, Mehta V (2014) Umbilical venous catheter retrieval in a $970 \mathrm{gm}$ neonate by a novel technique. Ann Pediatr Cardiol 7: 52-54. [Crossref]

19. Venkatesh IH (2015) Broken Umbilical Vein Canula-A Rare Unavoidable Complication. International Journal of Gynecology, Obstetrics and Neonatal Care 2: 63-65.

20. Demirel A, Güven G, Okan F, Saygili A (2016) Successful percutaneous removal of broken umbilical vein catheter in a very low-birth-weight preterm infant. Turk Kardiyol Dern Ars 44: 700-702. [Crossref]

Copyright: (C2016 Habib M. This is an open-access article distributed under the terms of the Creative Commons Attribution License, which permits unrestricted use, distribution, and reproduction in any medium, provided the original author and source are credited. 